\title{
AMENDMENTS
}

\section{Publisher Correction: Following the fate of cells in vivo}

Jim Kling

Correction to: Lab Animal https://doi.org/10.1038/s41684-020-0602-5, published online 23 July 2020.

In the version of this article initially published, reference 6 (Muus et al.) was incorrect. The correct reference is as follows:

Quinn, J. J. et al. bioRxiv https://doi.org/10.1101/2020.04.16.045245 (2020)

The error has been corrected in the HTML and PDF versions of the article.

Published online: 9 October 2020

https://doi.org/10.1038/s41684-020-00682-y

(c) Springer Nature America, Inc. 2020

\section{Publisher Correction: Set lasers to image}

Ellen P. Neff

Correction to: Lab Animal https://doi.org/10.1038/s41684-020-0623-0, published online 12 August 2020.

In the version of this article initially published, in the section 'To the depths', the value for a wavelength was incorrect. In the sentence 'Whereas confocals emit visible wavelengths of light, 2P systems extend the wavelength to between 9000 and $1000 \mathrm{~nm}$, which reduces scattering and makes the brain appear more transparent', the number 9000 should have been 900 . The error has been corrected in the HTML and PDF versions of the article.

Published online: 9 October 2020

https://doi.org/10.1038/s41684-020-00681-z

(c) The Author(s), under exclusive licence to Springer Nature America, Inc. 2020

\section{Publisher Correction: The quest for an animal model of coral health and disease}

Ellen P. Neff

Correction to: Lab Animal https://doi.org/10.1038/s41684-019-0467-7, published online 27 January 2020.

In the version of this article initially published, in the section 'Don't be Astrangia,' the name Cavanaugh was incorrectly shown in two places as Kavanaugh. The error has been corrected in the HTML and PDF versions of the article.

Published online: 9 October 2020

https://doi.org/10.1038/s41684-020-00680-0

(C) The Author(s), under exclusive licence to Springer Nature America, Inc. 2020 